\title{
Global anthropogenic aerosol effects on convective clouds in ECHAM5-HAM
}

\author{
U. Lohmann \\ Institute of Atmospheric and Climate Science, ETH Zurich, Universitätsstr. 16, 8092 Zurich, Switzerland \\ Received: 18 September 2007 - Published in Atmos. Chem. Phys. Discuss.: 15 October 2007 \\ Revised: 25 January 2008 - Accepted: 7 March 2008 - Published: 14 April 2008
}

\begin{abstract}
Aerosols affect the climate system by changing cloud characteristics in many ways. They act as cloud condensation and ice nuclei and may have an influence on the hydrological cycle. Here we investigate aerosol effects on convective clouds by extending the double-moment cloud microphysics scheme developed for stratiform clouds, which is coupled to the HAM double-moment aerosol scheme, to convective clouds in the ECHAM5 general circulation model. This enables us to investigate whether more, and smaller cloud droplets suppress the warm rain formation in the lower parts of convective clouds and thus release more latent heat upon freezing, which would then result in more vigorous convection and more precipitation. In ECHAM5, including aerosol effects in large-scale and convective clouds (simulation ECHAM5-conv) reduces the sensitivity of the liquid water path increase with increasing aerosol optical depth in better agreement with observations and large-eddy simulation studies. In simulation ECHAM5-conv with increases in greenhouse gas and aerosol emissions since pre-industrial times, the geographical distribution of the changes in precipitation better matches the observed increase in precipitation than neglecting microphysics in convective clouds. In this simulation the convective precipitation increases the most suggesting that the convection has indeed become more vigorous.
\end{abstract}

\section{Introduction}

Anthropogenic aerosol particles such as sulfate and carbonaceous aerosols have substantially increased the global mean burden of aerosol particles from pre-industrial times to the present-day. Aerosols can interact with clouds and precip-

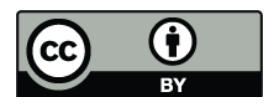

Correspondence to: $\mathrm{U}$. Lohmann (ulrike.lohmann@env.ethz.ch) itation by acting as cloud condensation or ice nuclei. The suite of possible impacts of aerosols through the modification of cloud properties is called indirect effects (Denman et al., 2007). The cloud albedo effect refers to the change in the radiative forcing at the top-of-the-atmosphere caused by an enhancement in cloud albedo from anthropogenic aerosols that lead to more and smaller cloud droplets for a given cloud water content. Estimates of the global annual mean radiative forcing of the cloud albedo effect range between -0.3 and $-1.8 \mathrm{~W} \mathrm{~m}^{-2}$ (Forster et al., 2007). Feedbacks due to the cloud lifetime effect, semi-direct effect or aerosol-ice cloud effects can either enhance or reduce the cloud albedo effect. Climate models estimate the sum of all aerosol effects (total indirect plus direct) to be $-1.2 \mathrm{~W} \mathrm{~m}^{-2}$ with a range from -0.2 to $-2.3 \mathrm{~W} \mathrm{~m}^{-2}$ in the change in the top-of-the-atmosphere net radiation since pre-industrial times, whereas inverse estimates constrain the indirect aerosol effect to be between -0.1 and $-1.7 \mathrm{~W} \mathrm{~m}^{-2}$ (Denman et al., 2007).

Rosenfeld (1999) and Rosenfeld and Woodley (2000) analyzed aircraft data together with satellite data suggesting that pollution aerosols suppress deep convective precipitation by decreasing cloud droplet size and delaying the onset of freezing. This hypothesis was supported with a cloud resolving model (Khain et al., 2001) such that supercooled cloud droplets down to $-37.5^{\circ} \mathrm{C}$ could only be simulated if the cloud droplets were small and numerous. In the same simulation, the ice crystals were smaller than $100 \mu \mathrm{m}$ so that the collision efficiencies between ice crystals and small cloud droplets were close to zero.

Cloud resolving studies suggest that precipitation from single-cell mixed-phase convective clouds is reduced under continental and maritime conditions when aerosol concentrations are increased (Yin et al., 2000; Khain et al., 2004; Seifert and Beheng, 2006). In the modelling study by Cui et al. (2006), this is caused by drops evaporating more rapidly in the high aerosol case (see also Jiang et al., 2006), which eventually reduces ice mass and hence precipitation.

Published by Copernicus Publications on behalf of the European Geosciences Union. 
Table 1. Sensitivity simulations.

\begin{tabular}{ll}
\hline Simulation & Description \\
\hline ECHAM5-acp & $\begin{array}{l}\text { Simulation with ECHAM5-HAM coupled to the double-moment cloud microphysics scheme only for } \\
\text { stratiform clouds (Lohmann et al., 2007) }\end{array}$ \\
ECHAM5-strat & $\begin{array}{l}\text { As ECHAM5-acp, but including some updates: } \\
\text { Consistent updraft velocity for transport and scavenging; depositional growth equation for deposition and sublimation; } \\
\text { increased entrainment rate for penetrative convection; accounting for the turbulent cooling } \\
\text { rate in the immersion freezing parameterization }\end{array}$ \\
As ECHAM5-strat, but employing the double-moment cloud microphysics scheme also in convective clouds \\
ECHAM5-conv & $\begin{array}{l}\text { As ECHAM5-strat, but using the greenhouse gas concentrations representative of 1750 and the sea surface } \\
\text { temperature from a coupled GCM/mixed-layer ocean simulation of a pre-industrial climate without }\end{array}$ \\
anthropogenic greenhouse gases and aerosols (Feichter et al., 2004) & As ECHAM5-strat-ghg, but employing the double-moment cloud microphysics scheme also in convective clouds \\
\hline
\end{tabular}

Khain et al. (2005) postulate that smaller cloud droplets, such as those originating from human activity, would change the thermodynamics of convective clouds. More, smaller droplets suppress the warm rain formation in the lower parts of convective clouds. When these droplets freeze, more liquid water is available for freezing, which releases more latent heat. This can then result in more vigorous convection and more precipitation. In a clean cloud, on the other hand, rain would have depleted the cloud so that less latent heat is released when the cloud glaciates, resulting in less vigorous convection and less precipitation. Similar results were obtained by Koren et al. (2005), Zhang et al. (2005), and for the multi-cell cloud systems studied by Seifert and Beheng (2006). For a thunderstorm in Florida in the presence of Saharan dust, the simulated precipitation enhancement only lasted two hours after which precipitation decreased as compared with clean conditions (Van den Heever et al., 2006). Tao et al. (2007) obtained decreases, no change or increases in precipitation from deep convective cloud systems as a response to anthropogenic aerosols depending on the evaporative cooling in the lower troposphere.

When aerosol effects on warm convective clouds are included in addition to their effect on warm stratiform clouds in global climate models, the overall indirect aerosol effect and the change in surface precipitation can be larger or smaller than if just the aerosol effect on stratiform clouds is considered (Nober et al., 2003; Menon and Rotstayn, 2006).

The adequate treatment of convection in general circulation models (GCMs) is one of the major uncertainties in climate modeling (Randall et al., 2003). Tost et al. (2006) studied the influence of different convection parameterizations including the Tiedtke scheme (Tiedtke, 1989) with modifications by Nordeng (1994) that is used in this study. They concluded that the differences between the different convective schemes are generally not very large and that each scheme has its particular aspects for which it performs comparatively well or less well. Thus, it cannot unequivocally be concluded which of the schemes is superior.

In this paper the microphysics of stratiform clouds has been extended to convective clouds (Zhang et al., 2005). Whereas Zhang et al. (2005) only introduced microphysics for the liquid and ice water mass mixing ratios, here the modifications to the number concentrations of cloud droplets and ice crystals and the coupling to the double-moment aerosol scheme ECHAM5-HAM are included as well. As compared to the studies by Nober et al. (2003) and Menon and Rotstayn (2006), here aerosols not only modify warm convective clouds, but influence the ice phase as well. The model is described in the next section. Section 3 presents a detailed model validation. Sensitivity studies of the cloud response to anthropogenic aerosols are subject of Sect. 4 and conclusions are given in Sect. 5.

\section{Model description}

\subsection{Standard model}

We use the ECHAM5 general circulation model (GCM) (Roeckner et al., 2003) to estimate the importance of aerosol effects on convective clouds. The version of ECHAM5 used in this study includes the double-moment aerosol scheme ECHAM5-HAM that predicts the aerosol mixing state in addition to the aerosol mass and number concentrations (Stier et al., 2005). The size-distribution is represented by a superposition of log-normal modes including the major global aerosol compounds sulfate, black carbon, organic carbon, sea salt and mineral dust.

A mass flux scheme is employed for shallow, midlevel, and deep convection (Tiedtke, 1989) with modifications for deep convection according to Nordeng (1994). The scheme is based on steady-state equations for mass, heat, moisture, cloud water, and momentum for an ensemble of updrafts and downdrafts, including turbulent and organized entrainment and detrainment. Cloud water detrainment in the upper part of the convective updrafts is used as a source term in the stratiform cloud water equations. For deep convection, an adjustment-type closure is used with convective activity expressed in terms of convective available potential energy 
ECHAM5-conv

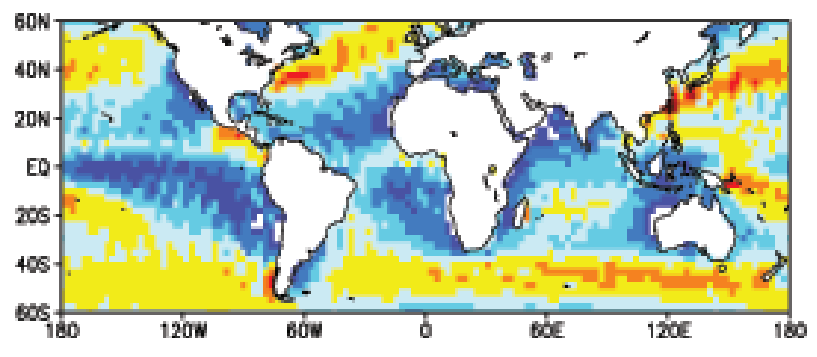

ECHAM5- acp

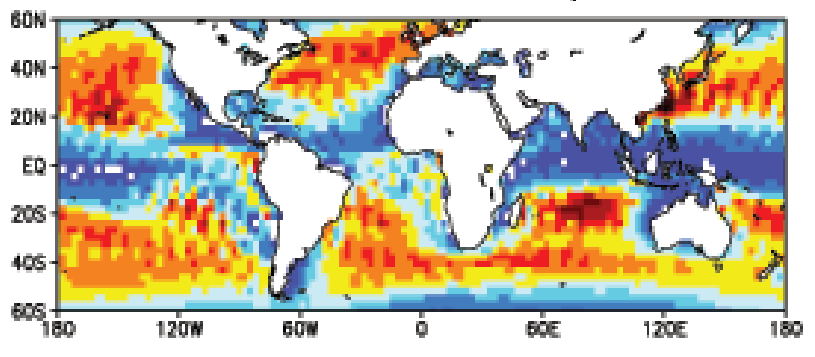

Satellite data (Greenwald)

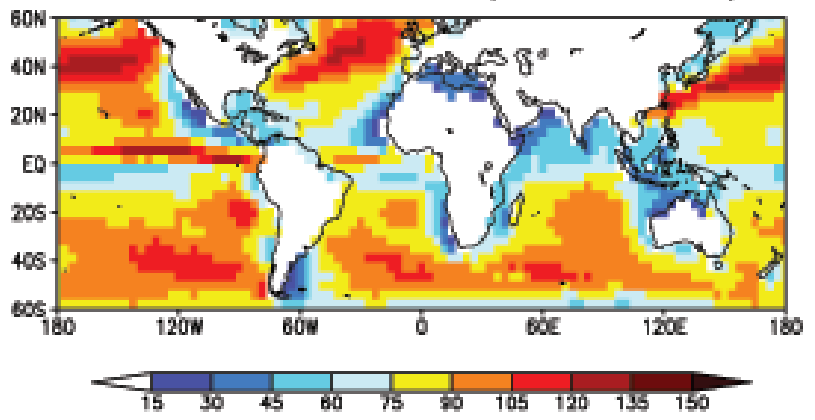

ECHAM5-strat

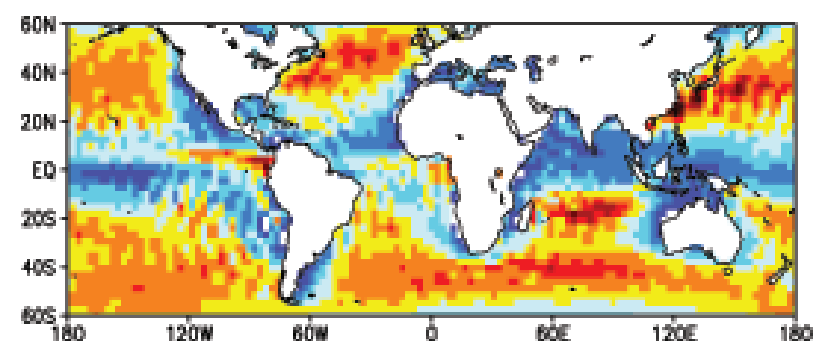

Satellite data (Ferraro)

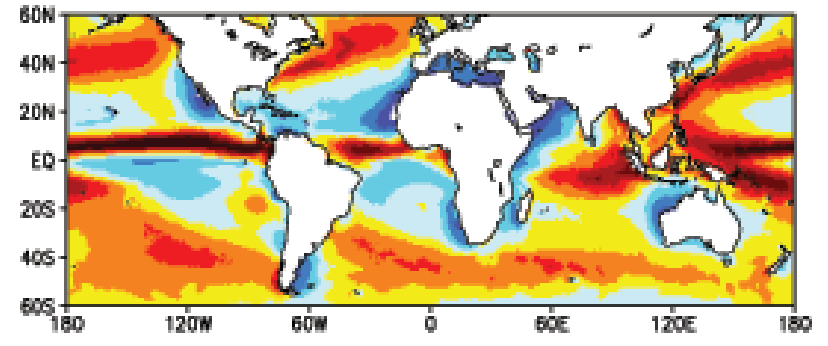

Satellite data (Weng\&Grody)

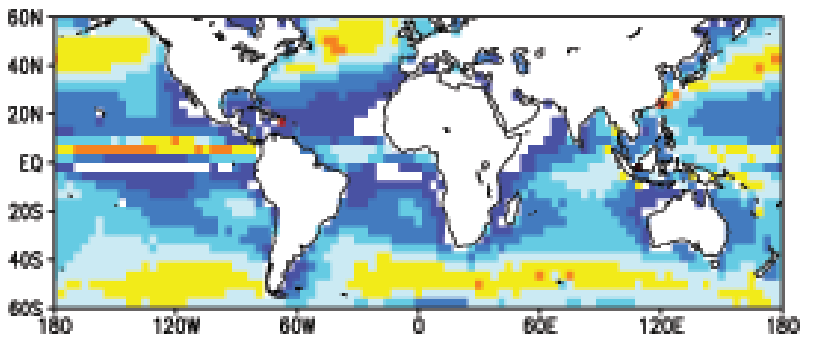

Fig. 1. Annual mean liquid water path $\left[\mathrm{g} \mathrm{m}^{-2}\right]$ from SSM/I observations by Ferraro et al. (1996), Greenwald et al. (1993), Weng and Grody (1994) and from the simulations ECHAM5-conv, ECHAM5-strat and ECHAM5-acp.

(Roeckner et al., 2006). The microphysics are very simple. At temperatures below $0^{\circ} \mathrm{C}$ only ice clouds are considered which assumes that freezing takes place instantaneously. The conversion from cloud water $q_{w}$ to precipitation $G$ is a function of the cloud water content and the vertical extent of the cloud:

$G=K(p) \cdot q_{w}$

where $K(p)=6 \cdot 10^{-4} \mathrm{~s}^{-1}$ if $\left(p_{b}-p\right)>p_{\text {crit. }}$. Here $p_{b}$ is the pressure at cloud base and the critical cloud thickness is given as $p_{\text {crit }}=150 \mathrm{hPa}$ (ocean) and $p_{\text {crit }}=300 \mathrm{hPa}$ (land).

The stratiform cloud scheme consists of prognostic equations for the water phases (vapor, liquid, solid), bulk cloud microphysics (Lohmann and Roeckner, 1996), and an empirical cloud cover scheme (Sundqvist et al., 1989). The microphysics scheme includes phase changes between the water components and precipitation processes (autoconversion, accretion, aggregation). Moreover, evaporation of rain and melting of snow are considered, as well as sedimentation of cloud ice. It also includes prognostic equations of the number concentrations of cloud droplets and ice crystals and has been coupled to the aerosol scheme ECHAM5-HAM (Lohmann et al., 2007).

The simulation with the standard model as described in this subsection is referred to as ECHAM5-acp (Table 1). It is compared to a simulation that includes modifications to the microphysics scheme in stratiform clouds (simulation ECHAM5-strat). ECHAM5-strat is the basis for the simulation in which the double-moment cloud microphysics scheme is included in convective clouds (simulation ECHAM5-conv). Both simulations are described below. 
Table 2. Annual global mean cloud and aerosol properties. Aerosol optical depth (AOD) is obtained from different observations (Kinne, 2008). The liquid water path (LWP) observations stem from SSM/I (Ferraro et al., 1996; Greenwald et al., 1993; Weng and Grody, 1994), and are restricted to oceans. Ice water path (IWP) has been derived from ISCCP data (Storelvmo et al., 2008) and includes data from land and oceans. Water vapor mass (WVM) data stem from MODIS. $N_{d}$ and $N_{i}$ refer to the vertically integrated cloud droplet and ice crystal number concentration, and $r_{\mathrm{e}}$ refers to the cloud top effective radius of liquid water clouds with cloud top temperatures warmer $273 \mathrm{~K}$.. Observations of $N_{d}$ and $r_{\mathrm{e}}$ are obtained from ISCCP (Han et al., 1998, 1994) and are limited to $50^{\circ} \mathrm{N}$ to $50^{\circ} \mathrm{S}$. Total precipitation $\left(P_{\text {tot }}\right)$ is taken from the Global Precipitation Climatology Project (Adler et al., 2003); the fraction of stratiform precipitation in the tropics $\left(20^{\circ} \mathrm{N}-20^{\circ} \mathrm{S}\right)$ from TRMM (Schumacher and Houze, 2003), total cloud cover (TCC) is obtained from surface observations (Hahn et al., 1994), ISCCP (Rossow and Schiffer, 1999) and MODIS data (King et al., 2003). The shortwave (SCF) and longwave cloud forcing (LCF) estimates are taken from Kiehl and Trenberth (1997). In addition estimates of LCF from TOVS retrievals (Susskind et al., 1997; Scott et al., 1999) are included. In cases where the observations are restricted geographically, the respective data from the different simulations are averages over the limited regions as well. Note that $r_{\mathrm{e}}$ and $N_{d}$ are sampled only over cloudy periods and over the cloudy part of the grid box.

\begin{tabular}{lrrrr}
\hline Simulation & ECHAM5-conv & ECHAM5-strat & ECHAM5-acp & OBS \\
\hline $\mathrm{LWP}_{\mathrm{g} \mathrm{m}} \mathrm{g} \mathrm{m}^{-2}$ & 59.3 & 69.2 & 64.6 & $49-84$ \\
$\mathrm{IWP}_{\mathrm{g} \mathrm{m}} \mathrm{g} \mathrm{m}^{-2}$ & 17.2 & 17.0 & 27.7 & 29 \\
$\mathrm{~N}_{d}, \mathrm{10}^{10} \mathrm{~m}^{-2}$ & 8.2 & 9.3 & 11.4 & 4 \\
$\mathrm{~N}_{i}, 10^{10} \mathrm{~m}^{-2}$ & 0.6 & 0.6 & 0.7 & \\
$\mathrm{r}_{e}, \mu \mathrm{m}$ & 10.2 & 10.8 & 10.5 & 11.4 \\
$\mathrm{WVM}, \mathrm{kg} \mathrm{m}^{-2}$ & 25.4 & 26.1 & 26.0 & 25.1 \\
$\mathrm{TCC}, \%$ & 61.4 & 65.1 & 62.5 & $62-67$ \\
$\mathrm{P}_{\text {tot }}, \mathrm{mm} \mathrm{d}^{-1}$ & 2.99 & 2.91 & 2.89 & 2.74 \\
$\mathrm{P}_{\text {strat }}, \mathrm{mm} \mathrm{d}^{-1}$ & 1.76 & 1.29 & 1.07 & \\
$\mathrm{P}_{\text {conv }}, \mathrm{mm} \mathrm{d}^{-1}$ & 1.23 & 1.62 & 1.82 & \\
$\left(\frac{P_{\text {strat }}}{P_{\text {tot }}}\right)_{20 \mathrm{~S}-20 \mathrm{~N}}, \%$ & 43 & 24 & 7 & 40 \\
SCF, $\mathrm{W} \mathrm{m}^{-2}$ & -51.3 & -53.8 & -52.4 & -50 \\
$\mathrm{LCF}, \mathrm{W} \mathrm{m}^{-2}$ & 29 & 30.3 & 29.2 & $22-30$ \\
AOD & 0.179 & 0.182 & 0.176 & $0.15-0.19$ \\
\hline
\end{tabular}

Table 3. Annual global mean changes in AOD, the hydrological cycle and the TOA radiative budget from 1750 to present-day. Note that total water path changes here refer to the average over land and ocean. As upward fluxes such as the outgoing longwave radiation (OLR) are negative in ECHAM, positive changes in OLR denote a decrease.

\begin{tabular}{|c|c|c|c|c|c|}
\hline Simulation & $\begin{array}{r}\text { ECHAM5- } \\
\text { conv }\end{array}$ & $\begin{array}{r}\text { ECHAM5- } \\
\text { strat }\end{array}$ & $\begin{array}{r}\text { ECHAM5- } \\
\text { acp }\end{array}$ & $\begin{array}{r}\text { ECHAM5- } \\
\text { conv-ghg }\end{array}$ & $\begin{array}{r}\text { ECHAM5- } \\
\text { strat-ghg }\end{array}$ \\
\hline AOD & 0.039 & 0.042 & 0.042 & 0.042 & 0.043 \\
\hline Total water path, $\mathrm{g} \mathrm{m}^{-2}$ & 4.5 & 6.1 & 6.9 & 3.5 & 5.5 \\
\hline Total cloud cover, \% & 0.5 & 0.5 & 0.25 & -0.4 & -0.2 \\
\hline Total precip., $\mathrm{mm} \mathrm{d}^{-1}$ & -0.012 & -0.018 & -0.008 & 0.01 & 0.012 \\
\hline Conv. precip., $\mathrm{mm} \mathrm{d}^{-1}$ & 0. & -0.005 & -0.006 & 0.02 & 0.013 \\
\hline Shortwave radiation TOA, $\mathrm{W} \mathrm{m}^{-2}$ & -1.7 & -1.9 & -2.0 & -0.4 & -1.0 \\
\hline Outgoing longwave rad., $\mathrm{W} \mathrm{m}^{-2}$ & 0.2 & 0.3 & 0.1 & 0.5 & 0.7 \\
\hline Net radiation TOA, $\mathrm{W} \mathrm{m}^{-2}$ & -1.5 & -1.6 & -1.9 & 0.0 & -0.3 \\
\hline
\end{tabular}

2.2 Microphysics in convective clouds and modifications to the standard model

In simulation ECHAM5-conv the simplified microphysics scheme in convective clouds is replaced by the doublemoment cloud microphysics scheme in stratiform clouds (Lohmann et al., 2007) retaining the critical cloud thickness before precipitation commences. A first study along these lines was carried out by Zhang et al. (2005), who introduced the bulk microphysics scheme for the mass mixing ratios of cloud liquid water and cloud ice and their conversion rates into convective clouds. Here we extend that approach to the number concentrations of cloud droplets and ice crystals and couple the convective microphysics scheme to the aerosol scheme ECHAM5-HAM. The cloud optical properties remain unchanged.

The aerosol activation in convective clouds is parameterized according to Lin and Leaitch (1997):

$Q_{\text {nucl }}=\frac{1}{\Delta t}\left(0.1\left(N_{l}^{\max }\right)^{1.27}\right)$ 


\section{ECHAM5-conv}

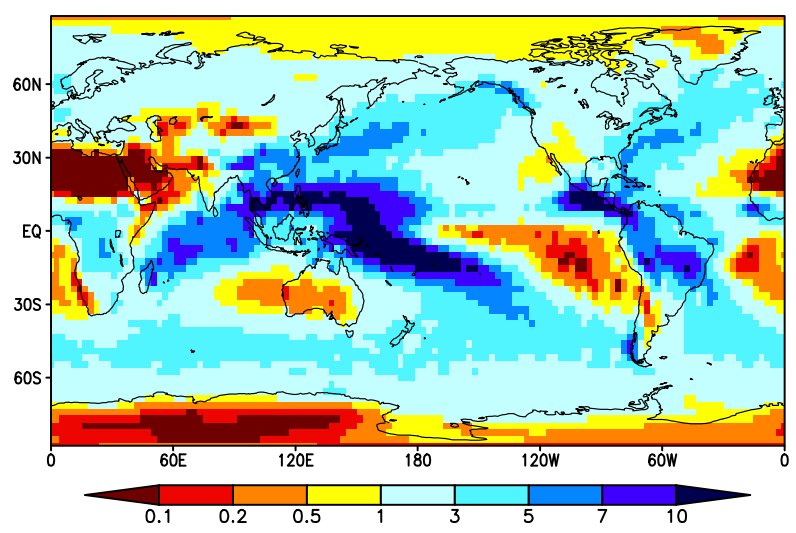

\section{ECHAM5- acp}
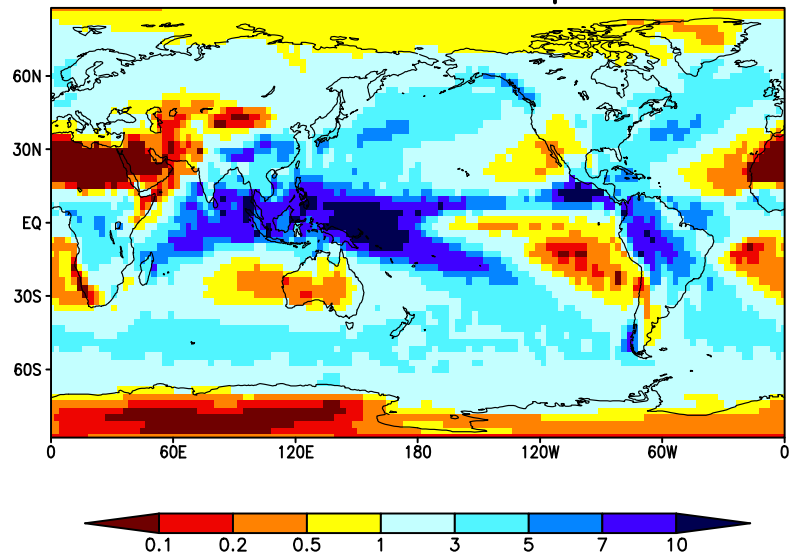

\section{ECHAM5-strat}

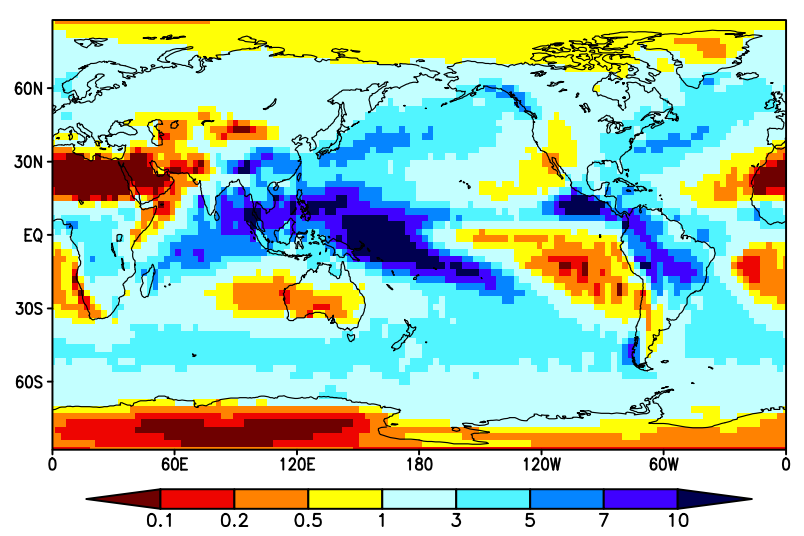

Observations
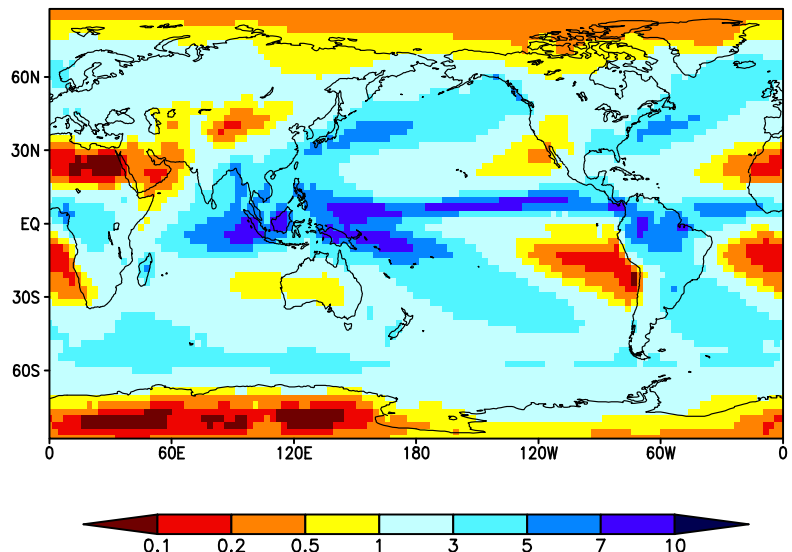

Fig. 2. Annual mean precipitation [mm d ${ }^{-1}$ ] from GPCP observations (Adler et al., 2003) and from the simulations ECHAM5-conv, ECHAM5-strat and ECHAM5-acp.

where

$N_{l}^{\max }=\frac{\left(N_{a}-N_{l, \text { old }}\right) w}{w+\alpha\left(N_{a}-N_{l, \text { old }}\right) w}$

for $N_{l},{ }^{\max }$ in $\mathrm{cm}^{-3}, w$ in $\mathrm{cm} \mathrm{s}^{-1}$ and and $\alpha=0.023 \mathrm{~cm}^{4} \mathrm{~s}^{-1}$. The updraft velocity $w$ is obtained as the sum of the grid mean vertical velocity and a turbulent contribution expressed in terms of the turbulent kinetic energy (TKE) for stratiform clouds (Lohmann et al., 1999). For convective clouds also a contribution of the convectively available potential energy (CAPE) (Lohmann, 2002) has been added:

$w=\left\{\begin{array}{lr}\bar{w}+1.33 \sqrt{\mathrm{TKE}} & \text { stratiform clouds } \\ \bar{w}+2 \sqrt{\mathrm{CAPE}}+1.33 \sqrt{\mathrm{TKE}} \text { convective clouds }\end{array}\right.$

The contribution to the vertical velocity from CAPE follows elementary parcel theory (Rogers and Yau, 1989). Elementary parcel theory yields that the vertical velocity is proportional to $2 \sqrt{\mathrm{CAPE}}$. This is an upper estimate that can be found in convective cores in the absence of entrainment.
$N_{a}$ is the number concentration of the internally mixed aerosols beyond a certain wet radius. While the cutoff of $35 \mathrm{~nm}$ was chosen in stratiform clouds (Lohmann et al., 2007), we chose $25 \mathrm{~nm}$ for convective clouds. Because the vertical velocity is higher in convective clouds, more and smaller aerosols are activated according to Köhler theory. To take that into account, we potentially allowed all aerosols with wet radii larger $25 \mathrm{~nm}$ to be activated in convective clouds.

The other microphysical conversion rates inside convective clouds are autoconversion of cloud droplets to form rain drops, heterogeneous contact and immersion freezing of cloud droplets, aggregation of ice crystals to form snow and accretion of rain drops with cloud droplets and snow flakes with cloud droplets and ice crystals. Zhang et al. (2005) neglected the accretion of rain and snow falling into the grid box from above with cloud droplets and ice crystals, because the microphysics inside convective clouds are only calculated in rising updrafts. Contrary to that, we now take advantage of the preliminary calculations of the cloud updraft including 

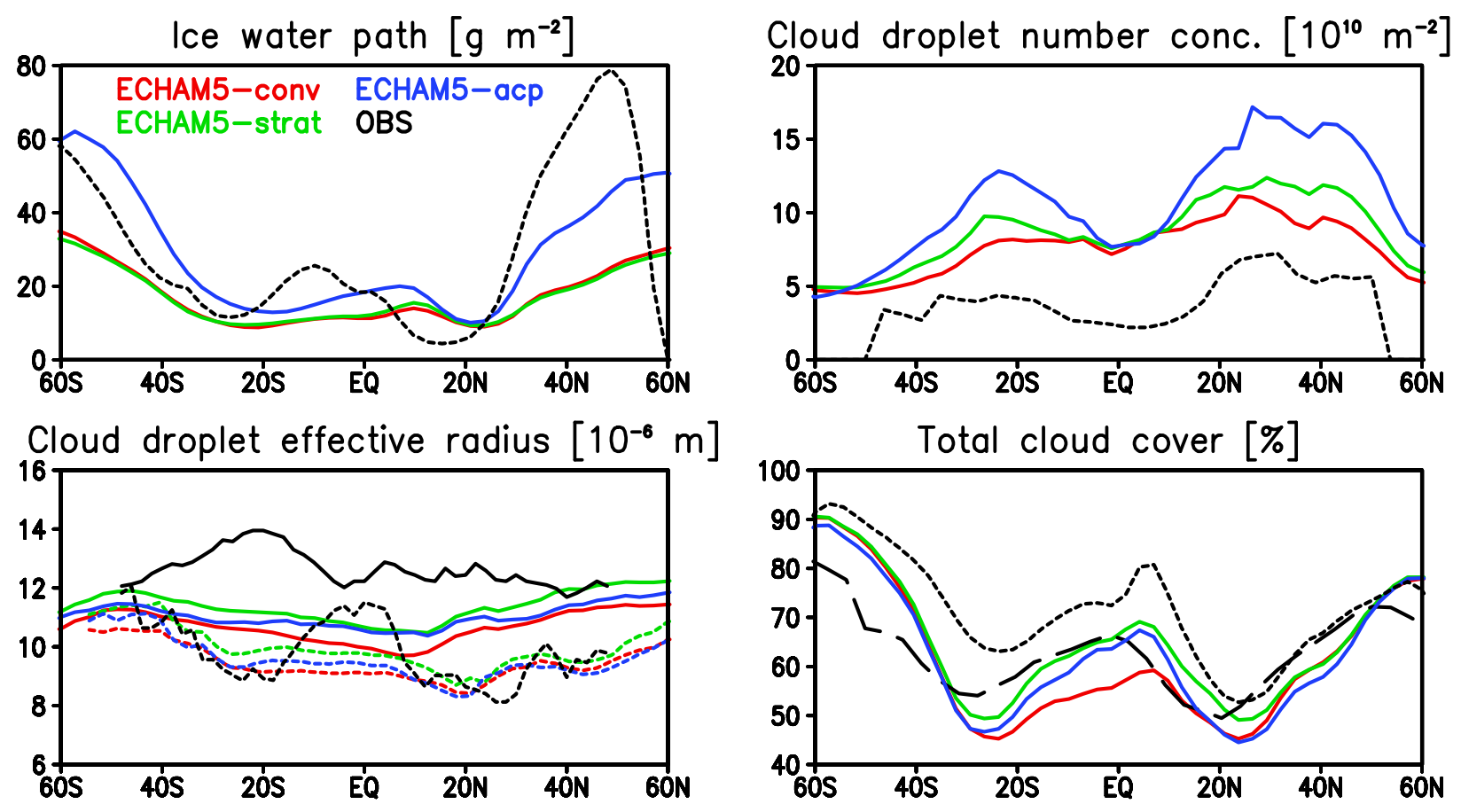

Fig. 3. Annual zonal means of ice water path (IWP), vertically integrated cloud droplet number concentration $\left(N_{d}\right)$, cloud top effective radius $\left(r_{e}\right)$ over oceans (solid lines) and over land (dotted lines), and total cloud cover from different model simulations described in Table 1 and from observations described in Table 2. Dotted black lines refer to ISCCP data for IWP, $N_{d}, r_{e}$ and total cloud cover. The dashed line refers to surface observations of total cloud cover (Hahn et al., 1994). Note that $r_{e}$ and $N_{d}$ are sampled only over cloudy periods and over the cloudy part of the grid box.

the microphysical processes in ECHAM that are conducted to estimate the vertical extend of the convective clouds and the level of neutral buoyancy. From these preliminary updraft calculations, we save the amount of rain and snow produced to calculate the accretion processes in the final updraft calculation.

Since supercooled cloud droplets can now exist down to $-35^{\circ} \mathrm{C}$ in convective clouds, we use the vapor pressure over liquid water and latent heat of vaporization as long as the ice water mixing ratio is below a threshold value of $0.5 \mathrm{mg} / \mathrm{kg}$ and switch to vapor pressure over ice and latent heat of sublimation otherwise. This treatment is consistent with what is done for stratiform clouds in ECHAM5 (Lohmann et al., 2007).

In ECHAM5-acp and ECHAM5-strat only the detrainment of cloud condensate as a source for the stratiform cloud liquid and ice mass mixing ratios is considered, but the number concentrations were obtained independently. With the introduction of sources and sinks for the cloud droplet and ice crystal number concentrations in convective clouds, ECHAM5-conv also includes detrainment of the cloud droplet and ice crystal number concentration from convective clouds as a source for stratiform clouds. When the cloud droplet respectively ice crystal number concentration from convective clouds exceeds the number concentration in stratiform clouds, then the difference is added to the respective number concentration in stratiform clouds.

In ECHAM5-conv the updraft velocity in convective cores $w_{u}=2 \mathrm{~m} \mathrm{~s}^{-1}$ is used to obtain cloud cover from the upward mass flux $M_{u}$ :

$b^{\text {conv }}=M_{u} /\left(w_{u} \rho\right)$

where $\rho$ is the air density. This formula is used in penetrative updrafts for the calculation of microphysics, for the evaporation of precipitation and for wet scavenging. While this value was also used in ECHAM5-acp for the convective cloud cover in the calculation of wet scavenging, a convective cloud cover of $5 \%$ was assigned for the calculation of the evaporation of precipitation. Eq. (5) is now also applied in ECHAM5-strat for the calculation of the evaporation of precipitation. In order to re-adjust the models radiation balance, the organized entrainment rate for penetrative convection has been doubled to $2 \times 10^{-4} \mathrm{~m}^{-1}$ in simulations ECHAM5-conv and ECHAM5-strat.

In addition to the changes in the convection scheme, two improvements were made to the microphysics in stratiform clouds in ECHAM5-strat and ECHAM5-conv that are different from what has been used in ECHAM5-acp: 

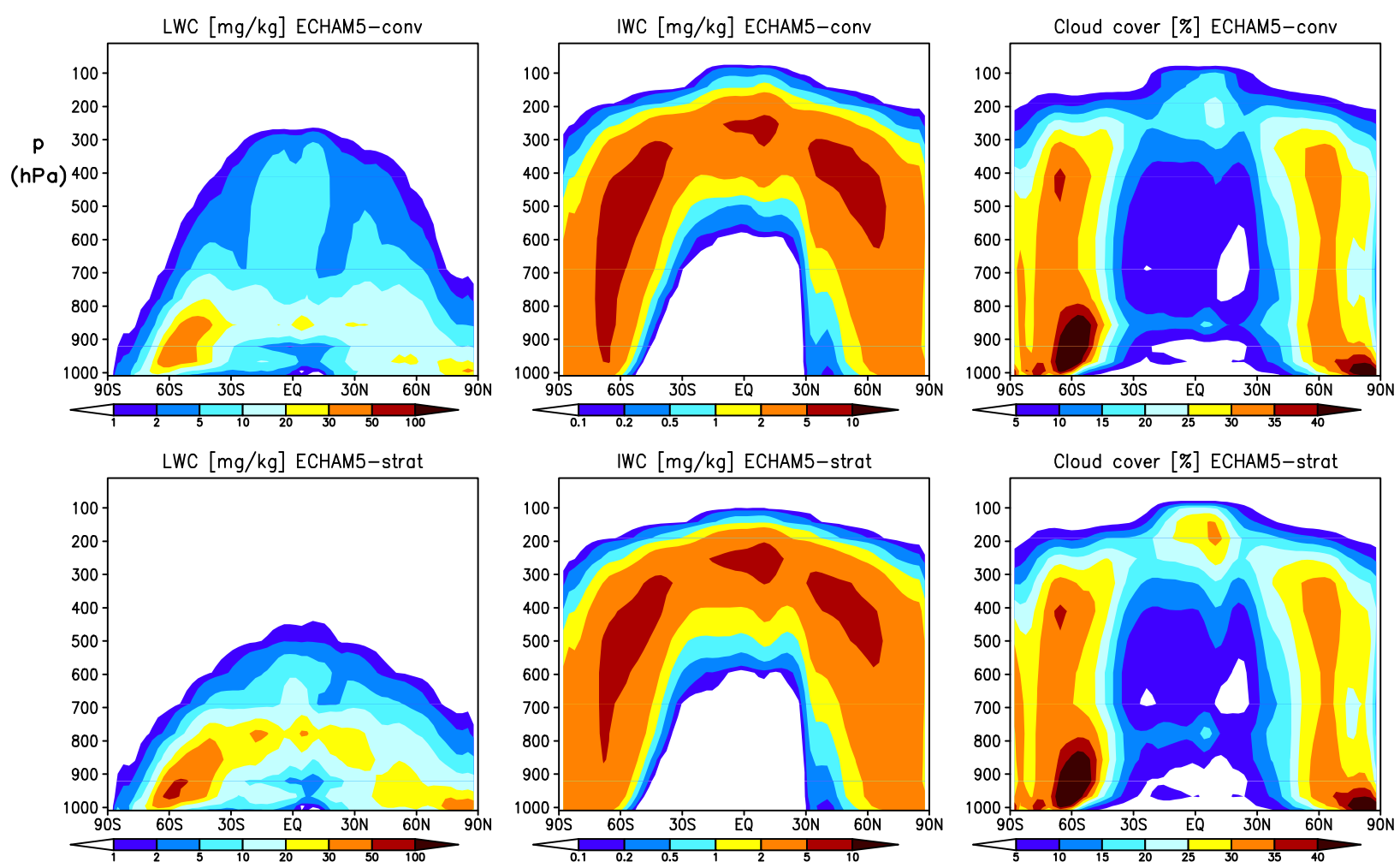

Fig. 4. Annual zonal mean latitude versus pressure plots of the grid-average mass mixing ratios (LWC, IWC) and cloud cover for simulations ECHAM5-conv and ECHAM5-strat.

1. The depositional growth equation for ice crystals, which was only applied for the growing crystals, is now also used to calculate sublimation of the ice crystals

2. The cooling rate that is used in the parameterization of immersion freezing of black carbon and dust aerosols now considers the enhanced cooling due to turbulent motions. The turbulent motions are obtained from TKE as described in Eq. (4) and in Hoose et al. (2008).

\subsection{Set-up of the simulations}

The ECHAM5 simulations have been carried out in T42 horizontal resolution $\left(2.8125^{\circ} \times 2.8125^{\circ}\right)$ and 19 vertical levels with the model top at $10 \mathrm{hPa}$ and a timestep of 30 minutes. All simulations used climatological sea surface temperature (SST) and sea-ice extent. They were simulated for 5 years after an initial spin-up of 3 months using aerosol emissions for the year 2000 (Dentener et al., 2006). To isolate the total anthropogenic aerosol effect, all simulations were repeated with aerosol emissions for pre-industrial times representative for the year 1750 (Dentener et al., 2006). The total anthropogenic effect investigated in this paper is not a forcing in the IPCC's definition of aerosol radiative forcing because it includes feedbacks from the cloud lifetime effect, the semi- direct effect and aerosol effects on ice clouds and allows adjustments of atmospheric temperatures.

In order to compare the change in precipitation over the last century with the sensitivity studies of the anthropogenic aerosol effect on both stratiform and convective clouds, we need to account for the changes in greenhouse gases and SST in addition to anthropogenic aerosols. Thus, we have repeated the pre-industrial simulations using pre-industrial greenhouse gas concentrations (Solomon et al., 2007) and added the difference in SST from a coupled GCM/mixedlayer-ocean (MLO) simulation between the present-day and a pre-industrial simulation in which anthropogenic greenhouse gases and aerosols have been turned off (Feichter et al., 2004) (simulations ECHAM5-strat-ghg and ECHAM5-convghg, see Table 1). The global mean change in surface temperature in these MLO simulations due to anthropogenic greenhouse gases and aerosols amounts to $0.6 \mathrm{~K}$ in good agreement with the observed warming during the 20th century (Feichter et al., 2004). The difference in SST between the presentday and the pre-industrial MLO simulation is used rather than the pre-industrial SST itself in order to avoid spurious SST changes stemming from differences in the climatological present-day SST and the present-day SST in the MLO simulation. 

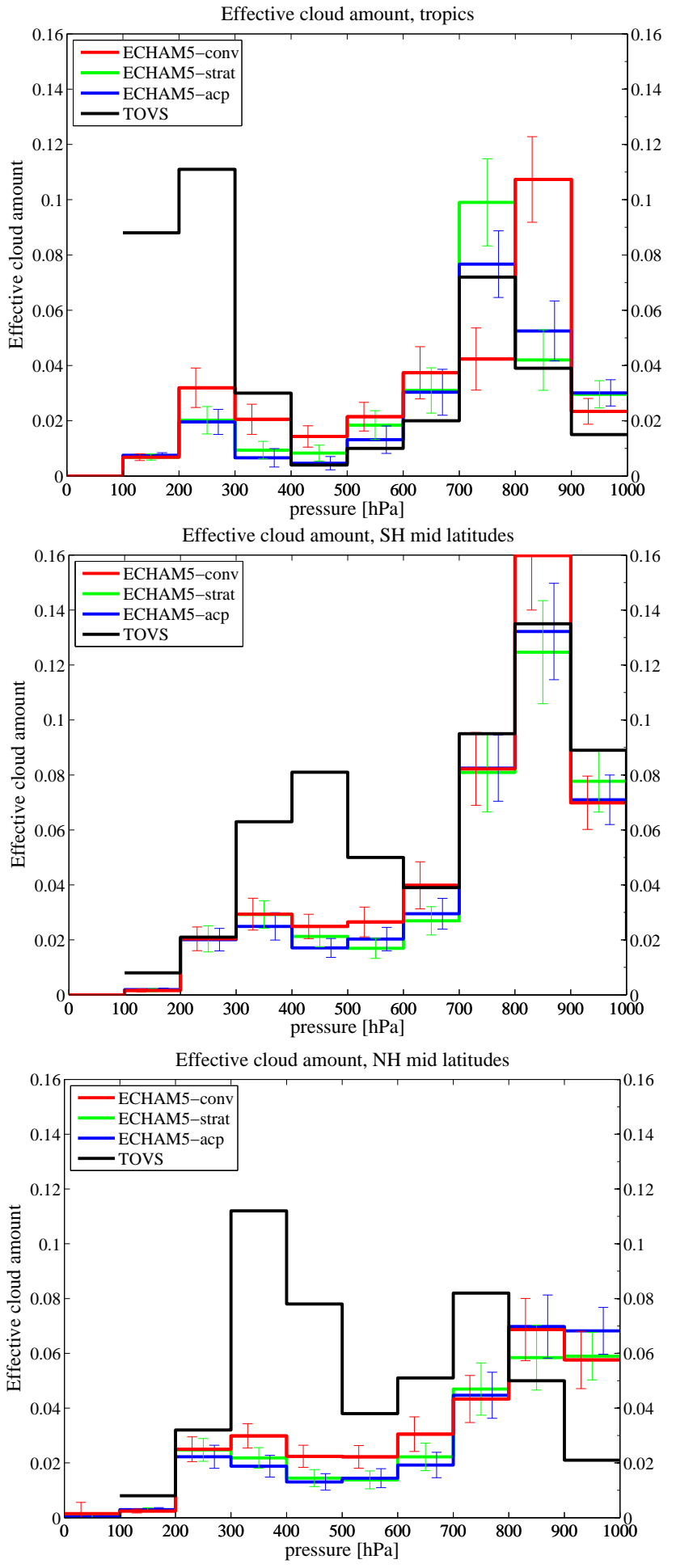

Fig. 5. Effective cloud amount (fraction) versus pressure in the tropics $\left(-13^{\circ} \mathrm{S}\right.$ to $\left.13^{\circ} \mathrm{N}\right)$, Southern $(\mathrm{SH})$ and Northern $(\mathrm{NH})$ Hemisphere midlatitudes $\left(32^{\circ}-60^{\circ} \mathrm{S} / \mathrm{N}\right)$ from collocated TOVS-LITE data (Stubenrauch et al., 2005) for September 1994 with simulated data for September from ECHAM5-conv, ECHAM5-strat and ECHAM5-acp.

\section{Model evaluation}

The validation of the coupled aerosol-cloud microphysics scheme in stratiform clouds has been described in Lohmann et al. (2007). Here we focus on the differences of ECHAM5conv and ECHAM5-strat, and between ECHAM5-strat and ECHAM5-acp.

An overview of the global-mean cloud and aerosol properties is given in Table 2. The simulations are conducted such that the global annual mean radiation budget is balanced to within $1 \mathrm{~W} \mathrm{~m}^{-2}$ at the top-of-the-atmosphere (TOA) and that the values of the shortwave and longwave cloud forcing are within the uncertainty of the radiative flux measurements of $\pm 5 \mathrm{~W} \mathrm{~m}^{-2}$ as reported by Kiehl and Trenberth (1997).

The largest difference between ECHAM5-strat and ECHAM5-acp is the decrease in the stratiform ice water path. This is due to the re-adjustment of the radiation balance after inclusion of the changes to the model as described above and in Table 1. It required a slight enhancement of the autoconversion rate resulting in more precipitation, especially stratiform precipitation, at the surface and fewer cloud droplets in the atmosphere.

The most noticeable difference between ECHAM5-conv and ECHAM5-strat is the different contribution from convective versus stratiform clouds of the total precipitation. In ECHAM5-conv, the convective contribution of the total precipitation is markedly decreased, from 56\% in ECHAM5strat to $41 \%$ in ECHAM5-conv because the precipitation formation in convective clouds is slower in ECHAM5-conv with the double-moment microphysics scheme over both land and oceans. While no observations are available that suggest how much of the precipitation should originate from convective precipitation globally, TRMM observations in the tropics $\left(20^{\circ} \mathrm{N}-20^{\circ} \mathrm{S}\right)$ suggest that $40 \%$ of the precipitation stems from stratiform clouds (Schumacher and Houze, 2003). In ECHAM5-strat the stratiform precipitation fraction in the tropics only accounts to $24 \%$ while it accounts to $43 \%$ in ECHAM5-conv in better agreement with the observations. As a result of the larger amount of total precipitation in ECHAM5-conv, the wet scavenging of aerosols is slightly enhanced causing the global mean aerosol optical depth to be a little bit smaller than in ECHAM5-strat (Table 2).

Even though detrainment from convective clouds is an additional a source for the stratiform cloud droplet number concentrations in ECHAM5-conv, the vertically integrated cloud droplet concentrations within the cloudy part of the grid box in stratiform clouds is actually smaller in ECHAM5-conv than in ECHAM5-strat (Table 2). This results from having increased the autoconversion rate in this simulation as described below. It is, however, at least twice as large as observed from ISCCP by Han et al. (1998) in all simulations. Note that the previous good agreement in Lohmann et al. (2007) is fortuitous because there we erroneously compared the simulated averaged cloud droplet number concentration 

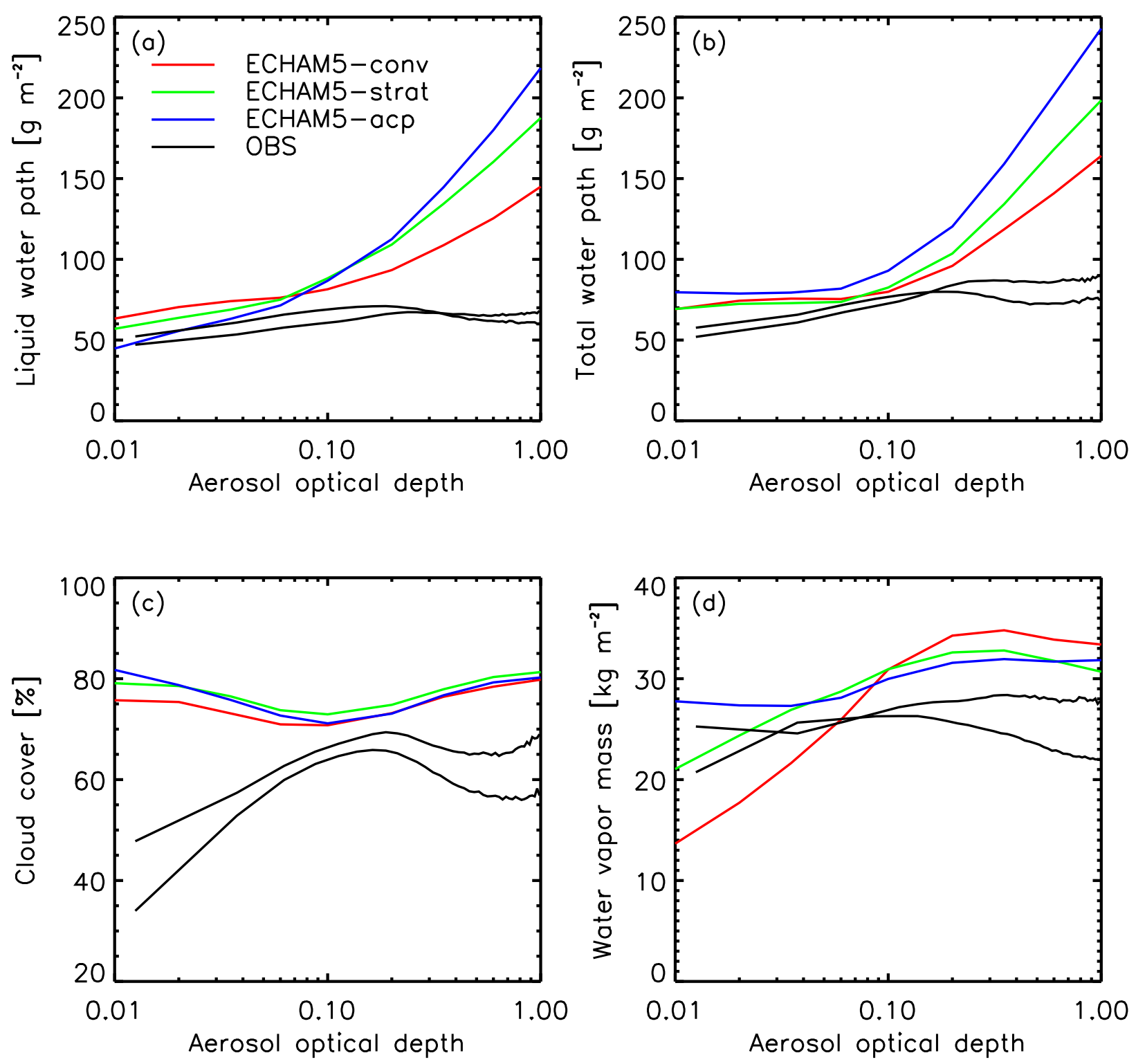

Fig. 6. Observed relationships between aerosol optical depth with (a) liquid water path, (b) total water path (sum of liquid and ice water path), (c) total cloud cover and (d) water vapor mass obtained from the MODIS instruments on board the AQUA and TERRA satellites (Myhre et al., 2007) and compared to the simulated relationships from ECHAM5-conv, ECHAM5-strat and ECHAM5-acp.

over clear and cloudy periods with the observed cloud droplet number concentration sampled only over cloudy events.

The global mean cloud top effective radius of warm clouds (with cloud top temperatures $>0^{\circ} \mathrm{C}$ ) sampled only over cloudy events in the cloudy part of the grid box is smaller in all simulations than estimated from ISCCP (Han et al., 1994). It is $0.6 \mu \mathrm{m}$ smaller in ECHAM5-conv than in ECHAM5strat because a larger number of activated cloud droplets in convective clouds than in stratiform clouds is a source for droplets in stratiform clouds in ECHAM5-conv. This leads to an increase in the cloud droplet number concentration and a decrease in the size of the droplets per given liquid water content and increases the shortwave cloud forcing. Thus, less shortwave radiation is absorbed at the top-of-the-atmosphere causing an imbalance in the net radiation. In order to bring the top-of-the-atmosphere radiation balance back into equilibrium, the autoconversion rate in stratiform clouds is enhanced by $60 \%$ in simulation ECHAM5-conv. In principle one could have adjusted other parameters, but this parameter is the most straight forward as an increase in autoconversion rate causes a reduction in the liquid water path and the vertically integrated cloud droplet number (Table 2), thus 

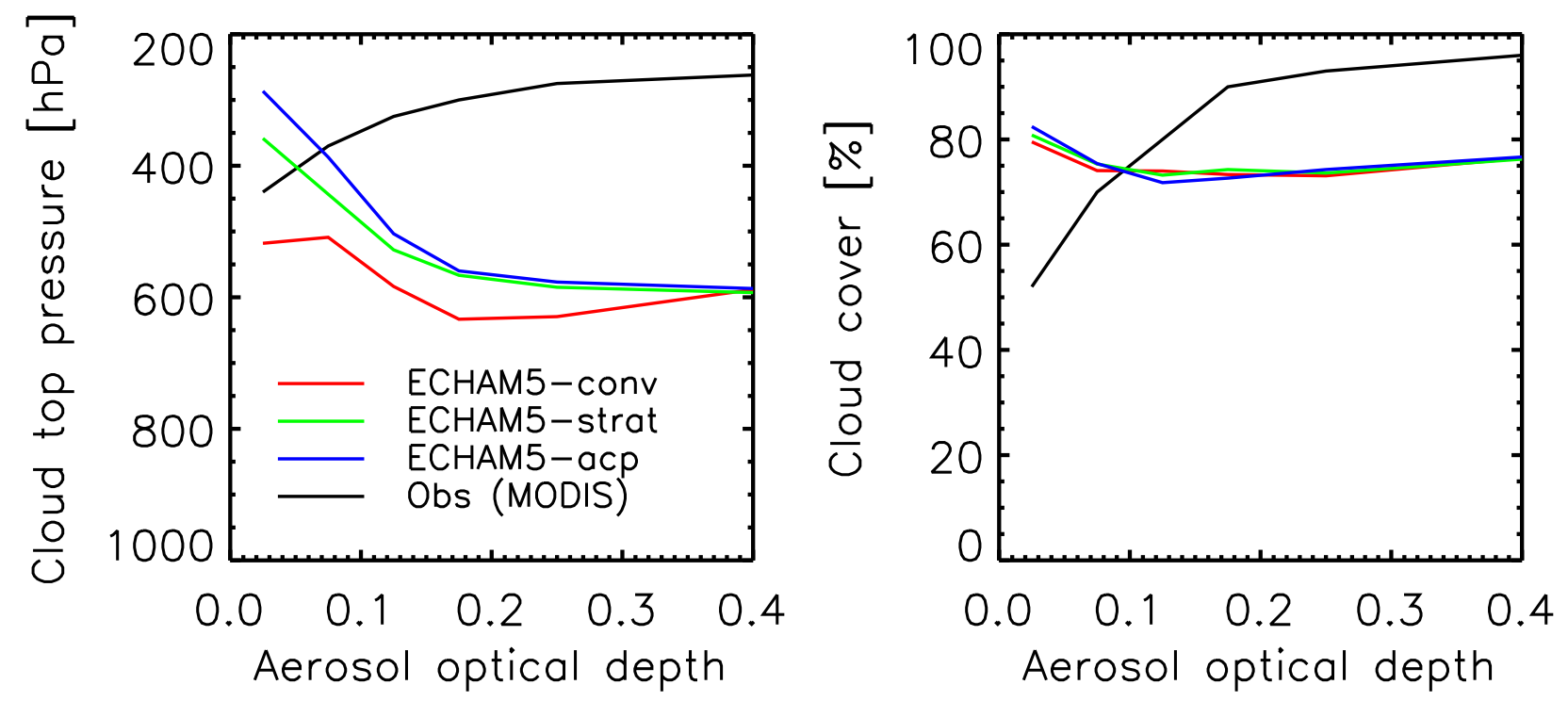

Fig. 7. Observed relationships between aerosol optical depth with cloud top pressure of convective clouds and cloud cover obtained from MODIS satellites over the North Atlantic (Koren et al., 2005) and compared to the simulated relationships from ECHAM5-conv, ECHAM5strat and ECHAM5-acp.

reducing the shortwave cloud forcing and increasing the net shortwave radiation at the top-of-the-atmosphere. The differences in the shortwave and longwave cloud forcing are small between the different simulations and agree to within $4 \mathrm{~W}$ $\mathrm{m}^{-2}$ with the ERBE observations (Table 2).

The annual mean liquid water path from stratiform clouds including detrainment from convective clouds is shown in Fig. 1. Maxima in observed liquid water path are found in the Intertropical convergence zone (ITCZ) and in the extratropical storm tracks (Ferraro et al., 1996; Greenwald et al., 1993; Weng and Grody, 1994). The retrievals differ by a factor of two regarding the liquid water path in the tropics and by over $60 \%$ in the global mean, highlighting the problems that still exist with these observations. Only in the retrieval by Ferraro et al. (1996), the South Pacific convergence zone (SPCZ) is apparent. All simulations reproduce the liquid water path maxima in the extratropical storm tracks where the simulated values are encompassed by the measurement uncertainty. However, the liquid water path in the Pacific Warm Pool is underestimated in simulations ECHAM5-acp and ECHAM5-strat. In better agreement with observations, ECHAM5-conv simulates a higher liquid water path in the Intertropical and South Pacific convergence zones. It results from the slower precipitation formation in convective clouds in ECHAM5-conv as compared to ECHAM5-strat and ECHAM5-acp (cf. Table 2). This causes more cloud water and ice to be detrained from convective clouds, which then is a source for stratiform cloud water and ice (Fig. 1).

The annual mean precipitation is shown in Fig. 2. The observational data from the Global Precipitation Climatology Project (GPCP) (Adler et al., 2003) show maxima in pre- cipitation in the ITCZ, SPCZ and secondary maxima in the Southern and Northern Hemisphere storm tracks. All simulations overestimate precipitation in the Pacific Warm Pool region and the monsoonal precipitation. Precipitation along the ITCZ is underestimated in ECHAM5-conv and ECHAM5strat but captured in ECHAM5-acp. The agreement between simulated and observed precipitation is better in the extratropical storm tracks which suggests that improvements in the convection scheme besides the cloud microphysics would be necessary. Overall, the three simulations are closer to each other than any of them with the observations.

The ice water path is considerably smaller in simulations ECHAM5-conv and ECHAM5-strat than in ECHAM5-acp and as derived from ISCCP (Fig. 3). However, one has to keep in mind that the ice water path retrieval is even more uncertain than retrievals of the liquid water path.

The cloud droplet number concentration refers to the concentrations within the cloudy part of the grid box, sampled over cloudy periods only. Note that the annual mean cloud droplet number concentration as deduced from ISCCP by Han et al. (1998) is an average of only 4 months (January, April, July and October 1987) and therefore has to be regarded with caution. While the latitudinal distribution of the cloud droplet number concentration with maxima in the Northern Hemisphere mid latitudes is captured rather well, the magnitude is more than twice as large as observed in all simulations. It is actually smallest in ECHAM5-conv, and therefore is in best agreement with the observations.

The cloud top effective radius of warm clouds (with cloud top temperatures $>0^{\circ} \mathrm{C}$ ) has been derived separately over land and ocean from ISCCP (Han et al., 1994). It is larger 

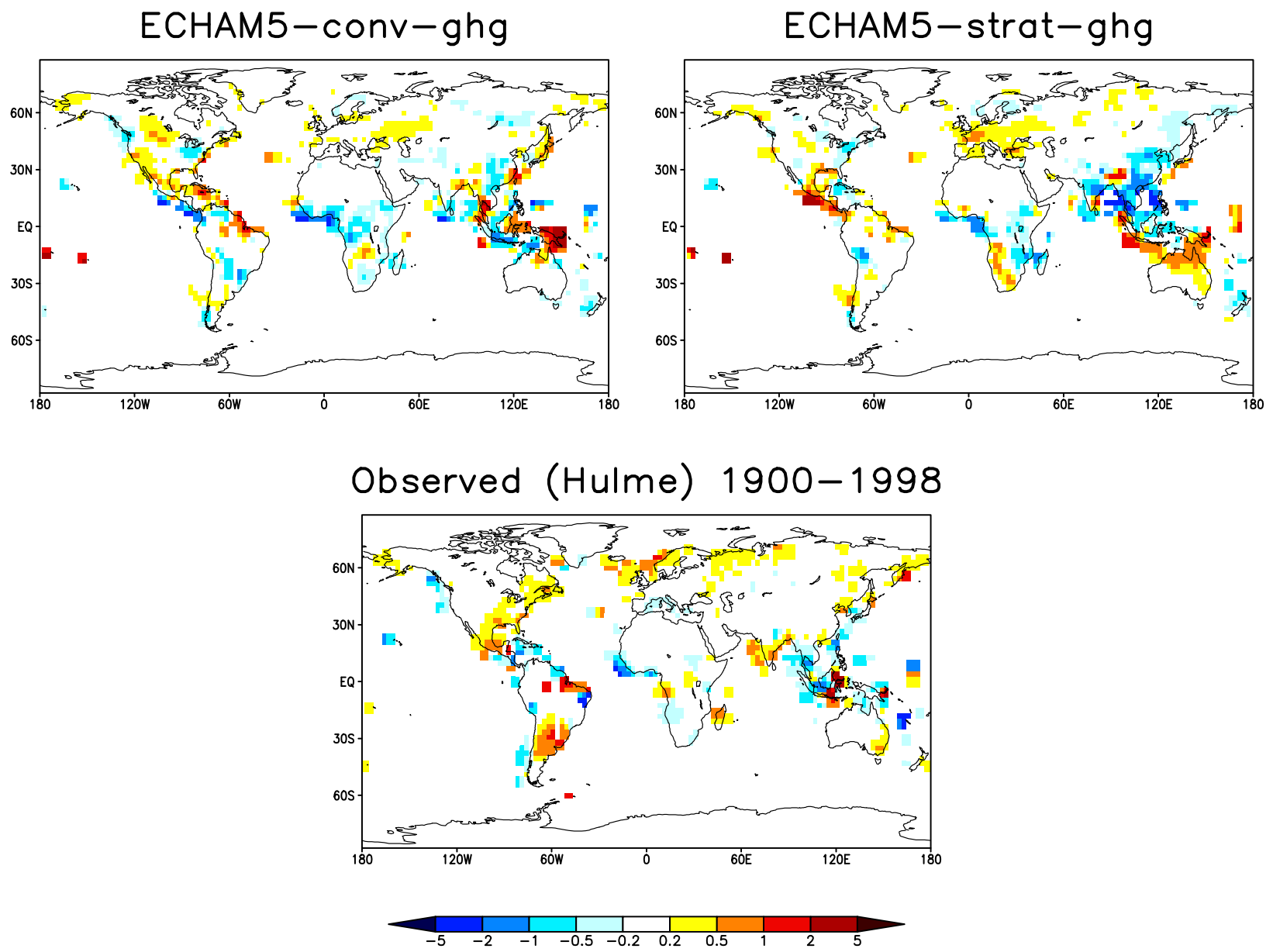

Fig. 8. Observed changes in precipitation $\left[\mathrm{mm} \mathrm{d}^{-1}\right.$ ] between the 10-year average from 1989-1998 minus the 10-year average from 19011910 (Hulme et al., 1998) as compared to simulated changes between the present-day and pre-industrial conditions for simulations ECHAM5conv-ghg and ECHAM5-strat-ghg. The simulated precipitation changes are shown only for data points where observational data are available.

over the oceans than over land and larger over the Southern Hemisphere than in the Northern Hemisphere. All simulations capture the size of the continental cloud droplets very well, but underestimate the size of the oceanic cloud droplets (Fig. 3).

Total cloud cover from stratiform clouds is reduced in simulation ECHAM5-conv as compared to simulation ECHAM5-strat in worse agreement with observations. This is especially pronounced in the tropics where the atmosphere is drier in ECHAM5-conv. As the Sundqvist cloud cover scheme only depends on the relative humidity, the cloud cover is reduced as well. Convective clouds themselves are considered as short-lived so that no cloud cover is assigned to them. They only contribute to the cloud cover by detraining condensate and subsequent formation of stratiform clouds. If one would assign the convective cores the same cloud cover that is calculated in Eq. (5), the agreement with the observations could be improved.

\subsection{Evaluation of cloud altitudes}

Including cloud microphysics in convective clouds has implications for the vertical distribution of cloud cover and cloud condensate. As shown in Fig. 4, the stratiform cloud liquid water extends to higher altitudes in simulation ECHAM5conv. On the other hand, fewer tropical cirrus clouds are found in ECHAM5-conv because the convective cloud tops do not extend as high vertically as in ECHAM5-strat. This means that the detrainment occurs at lower altitudes in ECHAM5-conv. The ice water content is very similar in both simulations.

Stubenrauch et al. (2005) derived the pressure of the highest cloud layer, weighted by the effective cloud amount and normalized to the total cloud amount from collocated TOVSLITE satellite data for 10 days in September 1994 (Fig. 5). The statistics look similar as compared to 8 years of SeptNov data from 1987 and 1994 obtained from TOVS alone (Stubenrauch et al., 2005). Effective cloud amount refers to 

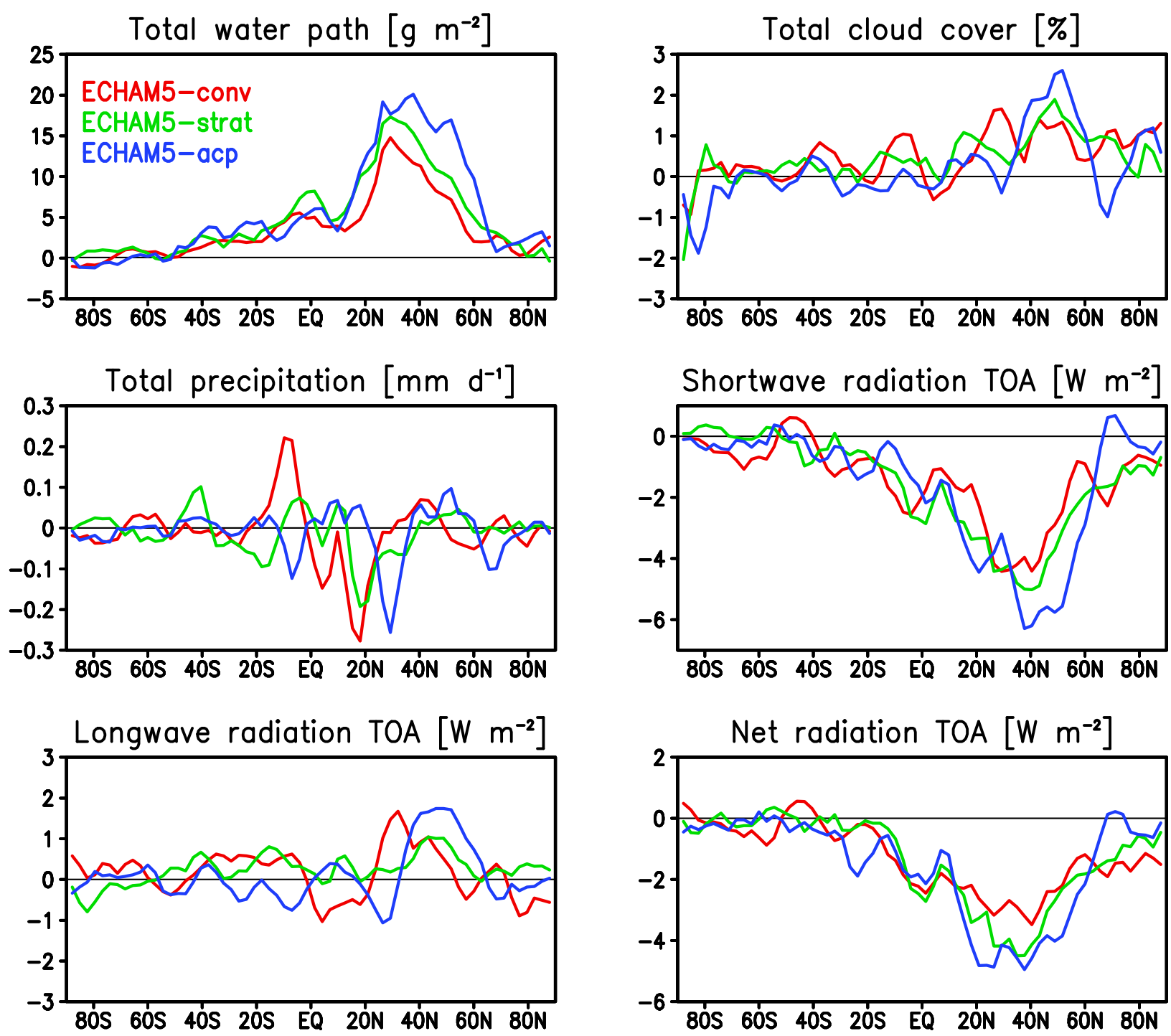

Fig. 9. Zonal annual mean changes in total water path (sum of liquid and ice water path), total cloud cover, total precipitation, shortwave, longwave and net shortwave radiation at the top-of-the-atmosphere due to the total anthropogenic aerosol effect for simulations ECHAM5conv, ECHAM5-strat, and ECHAM5-acp.

the frequency of occurrence of cloud amount multiplied by its emissivity. The model data for comparison have been obtained from 5 years of September data and were calculated in the same way.

As shown in Fig. 5, the effective cloud amount from stratiform clouds in the tropics peaks between 200 and $300 \mathrm{hPa}$ with a secondary maximum at the top of the boundary layer between 700 and $800 \mathrm{hPa}$. The satellite data suggest a much larger cloud amount above $300 \mathrm{hPa}$ than simulated in any ECHAM5 simulation. The increase in cloud amount in ECHAM5-conv at altitudes above $400 \mathrm{hPa}$ is a small step in the right direction, but the agreement at lower altitudes is worse.
The effective cloud amount in Southern Hemisphere midlatitudes is vastly different from the tropics with the maximum cloud amount between 800 and $900 \mathrm{hPa}$ and a secondary maximum between 400 and $500 \mathrm{hPa}$ (Fig. 5). All simulations capture the maximum between 800 and $900 \mathrm{hPa}$ but severely underestimate the cloud amount at higher altitudes. The slight increase in effective cloud amount in ECHAM5conv at altitudes above $700 \mathrm{hPa}$ again is a small improvement towards higher cloud amounts.

The effective cloud amount in Northern Hemisphere midlatitudes peaks between 300 and $400 \mathrm{hPa}$ with a secondary maximum between 700 and $800 \mathrm{hPa}$ (Fig. 5). All simulations produce the highest cloud amount below $800 \mathrm{hPa}$. In ECHAM5-conv, a secondary maximum between 300 and 
$400 \mathrm{hPa}$ is hinted at, but is far too small as compared to observations. As for the Southern Hemisphere, the small increase in cloud amount at altitudes above $700 \mathrm{hPa}$ and the small decrease below $900 \mathrm{hPa}$ in ECHAM5-conv slightly improves the vertical distribution of effective cloud cover.

The slight increase in effective cloud cover in simulation ECHAM5-conv in the mid troposphere that is apparent in all plots of Fig. 5 stems from the larger amount of supercooled water in these clouds (cf. Fig. 4) which increases their emissivity. The overall underestimation of high clouds can partly be explained by a higher sensitivity of the satellites to optically thin cirrus clouds than present in ECHAM5. It could also point to the importance of cloud dynamics as opposed to cloud microphysics as the reason for this discrepancy because the differences between the observations and the model simulations are larger than the inter-model differences. This will be subject to further investigations in the future.

\subsection{Evaluation of aerosol-cloud interactions}

Aerosol-cloud interactions are validated using observations from the MODIS satellites between $50^{\circ} \mathrm{S}$ and $50^{\circ} \mathrm{N}$ for two full years (2001 for MODIS on board of the Terra satellite and 2003 for MODIS on board the Aqua satellite) following Myhre et al. (2007). The observations show a modest increase of liquid (LWP) and total water path (TWP, sum of liquid and ice water path) with aerosol optical depth (AOD) and a rather strong increase of cloud cover with AOD especially for AOD $<0.2$ (Fig. 6). As suggested by the authors, this strong increase in cloud cover with AOD for AOD $<0.2$ is a result of aerosol-cloud interactions and a prolonged cloud lifetime. Large and mesoscale weather systems seem not to be a cause for the increase in cloud cover with AOD in this range. Additionally, part of the observed relationship of AOD with cloud cover can be explained by the larger water uptake close to the clouds since relative humidity is higher in regions with higher cloud cover. At AOD >0.2, LWP, TWP, cloud cover and water vapor mass decrease with increasing AOD.

The increase in LWP and TWP with AOD for small AOD values $(\mathrm{AOD}<0.1)$ as observed is captured in all model simulation. While the observed decrease in LWP for AOD $>0.2$ is not reproduced in any simulation, the sensitivity of LWP and TWP changes with increasing AOD is smallest in simulation ECHAM5-conv in best agreement with the observations. On the other hand, the sensitivity of the water vapor mass with increasing AOD is vastly overestimated in this simulation. Part of the differences in sensitivity between ECHAM-acp and ECHAM5-conv stem from the modifications to the large-scale microphysics scheme because the slopes the increases in LWP and water vapor mass with increasing AOD in ECHAM5-strat lie between the slopes for ECHAM5-acp and ECHAM5-conv (Fig. 6).

The increase in cloud cover with AOD at AOD $<0.2$ is not captured in any model simulation. Instead the trend is reversed such that the cloud cover decreases at small values of AOD and increases at higher values. This may be an artifact of the Sundqvist cloud cover scheme that depends only on relative humidity and hence is not very sensitive to changes in cloud condensate. On the other hand, multi-year analyses of data at the ARM site show that cloud fraction increases with AOD only for clouds of less than $1 \mathrm{~km}$ but decreases with increasing AOD for larger clouds (Kassianov et al., 2007). Thus, the global correlations have to be viewed with caution.

Water vapor mass is very sensitive to increases in AOD in simulation ECHAM5-conv and to a lesser extent in ECHAM5-strat. This suggests that data points with low values of AOD in ECHAM5-conv stem from drier geographical regions than in the other two simulations and in the observations. These low values of water vapor mass of less than $20 \mathrm{~kg} \mathrm{~m}^{-2}$ are limited to orographic terrain and mid- to high latitudes. In simulations ECHAM5-acp and ECHAM5-strat, on the other hand, low values of AOD can also be found in more humid regions causing a higher average water vapor mass for low values of AOD in better agreement with observations.

Koren et al. (2005) analyzed the cloud top heights from MODIS satellite data as a function of AOD for convective clouds over the Atlantic. As found globally by Myhre et al. (2007), cloud cover increases with increasing AOD. More interesting though, the convective clouds extend to higher altitudes when AOD increases (Fig. 7). The authors thus suggest that aerosols invigorate convective storms by suppressing drizzle so that more cloud water is available for freezing. This results in a larger latent heat release as compared to clean clouds and allows the clouds to penetrate to higher altitudes (see also Khain et al. (2005) discussed in the introduction). In ECHAM5-acp and ECHAM5-strat, the diagnosed convective cloud top heights show the opposite trend with AOD. They decrease from $300 \mathrm{hPa}$ at the cleanest AOD to $600 \mathrm{hPa}$ for the highest AOD. While ECHAM5-conv underestimates the diagnosed convective cloud top heights throughout, it nevertheless predicts the right trend of an increase in convective cloud top height for AOD values $>0.2$.

\section{Sensitivity studies of the anthropogenic aerosol effect on stratiform and convective clouds}

The observed change in precipitation from 1900 to 1998 has been reported by Hulme et al. (1998). While the observations show an increase of $0.02 \mathrm{~mm} / \mathrm{d}$ since the beginning of the last century, the precipitation decreases in simulations ECHAM5-acp, ECHAM5-strat and ECHAM5-conv through direct, semi-direct and indirect aerosol effects on the hydrological cycle (Table 3). Whereas the decrease in precipitation is dominated by convective precipitation in ECHAM5acp, the convective precipitation remains constant in simulation ECHAM5-conv. Because the change in precipitation 
over the last century is influenced by changes in greenhouse gases in addition to changes in aerosols, the pre-industrial simulations ECHAM5-strat and ECHAM5-conv have been repeated using pre-industrial greenhouse gas concentrations and pre-industrial sea surface temperatures (cf. Table 1). In these simulations (ECHAM5-conv-ghg and ECHAM5-stratghg) the observed global mean temperature increase of $0.6 \mathrm{~K}$ over the 20th century is taken into account. This results in a global mean increase of precipitation since pre-industrial times of $0.012 \mathrm{~mm} / \mathrm{d}$ in simulation ECHAM5-strat-ghg and of $0.01 \mathrm{~mm} / \mathrm{d}$ in simulation ECHAM5-conv-ghg (Table 3). The observed increased in precipitation over the 20th century calculated from the data in Fig. 8 amounts to $0.02 \mathrm{~mm} / \mathrm{d}$. The simulated change in precipitation sampled over the available data points from Fig. 8 only, results however in a decrease of $-0.02 \mathrm{~mm} / \mathrm{d}$ in ECHAM5-strat-ghg and of $-0.01 \mathrm{~mm} / \mathrm{d}$ in ECHAM5-conv-ghg. The increase in convective precipitation exceeds the increase in total precipitation in simulations ECHAM5-conv-ghg and ECHAM5-strat-ghg suggesting a strengthening of the convective activity in a warmer climate in these simulations. This is opposite to the small changes in convective activity found when doubling $\mathrm{CO}_{2}$ in the GISS GCM (Del Genio et al., 2007).

Figure 8 shows the observed change in precipitation between the 10-year average from 1989-1998 minus the 10year average from 1901-1910. Increases in precipitation can be seen in eastern North America, Northern Europe, Northern Asia, India, Brazil and Argentina, whereas precipitation decreased in the Pacific Warm Pool, in the Sahel zone, Central America and off the east coast of America. The decrease in the Sahel zone has partly been attributed to a cooling of the Northern Atlantic possibly enhanced by anthropogenic aerosols (Williams et al., 2001; Rotstayn and Lohmann, 2002; Held et al., 2005).

ECHAM5-conv-ghg captures the increase in precipitation in northern South America, Southern Africa, Western Europe and Eastern North America as well as the decrease in precipitation in the Sahel zone, in the Eastern North Pacific and parts of Indonesia. However, the observed increases in precipitation in Northern Asia and in India are missing in this simulation. Some of these features are also apparent in simulation ECHAM5-strat-ghg. In this simulation even the increase in precipitation in Northern Asia is captured, but therefore the increase in precipitation in North America is shifted from the coast too far inland.

The annual zonal mean changes in total water path (sum of liquid and ice water path), total cloud cover, total precipitation, shortwave, longwave and net radiation at the top-of-theatmosphere due to the total anthropogenic aerosol effect are shown in Fig. 9. The increase in AOD, which can be taken as a surrogate for the aerosol forcing, is smallest in simulation ECHAM5-conv, where the autoconversion rate and thus the wet scavenging is highest (Table 3). Total water path has increased the most in Northern Hemisphere midlatitudes as a response to the maximum in anthropogenic aerosol emis- sions. The increase in total water path is smallest in simulation ECHAM5-conv consistent with the smaller sensitivity of the change in total water path with increasing AOD in this simulation (cf. Fig. 6). This is a step in the right direction as large eddy model simulations suggest that the total water path may even decrease when adding aerosols, e.g. (Ackerman et al., 2004; Jiang et al., 2006). Cloud cover increases between 0.25 and $0.5 \%$ globally in the simulations due to the cloud lifetime effect with the largest increase in Northern Hemisphere mid latitudes where the increases in total water path are highest (Fig. 9).

The decrease in TOA shortwave radiation of -1.9 to $-2 \mathrm{~W}$ $\mathrm{m}^{-2}$ is comparable in ECHAM5-acp and ECHAM5-strat because it depends on the increase in total water path and in total cloud cover. The smaller increase in total water path in simulation ECHAM5-conv as compared to ECHAM5-acp and ECHAM5-strat results in a smaller decrease in shortwave radiation at TOA of $-1.7 \mathrm{~W} \mathrm{~m}^{-2}$. The outgoing longwave radiation (OLR) also decreases because of the increase in cloud cover. Thus it slightly compensates the decrease in shortwave radiation at TOA. The decrease in OLR is largest in simulation ECHAM5-strat such the decrease in net radiation is comparable in simulations ECHAM5-conv and ECHAM5-strat with -1.5 to $-1.6 \mathrm{~W} \mathrm{~m}^{-2}$ (Table 3 ).

\section{Conclusions}

In this study, the double-moment cloud microphysics scheme developed for stratiform clouds of the ECHAM5 GCM has been extended to convective clouds. This includes the processes of aerosol activation, precipitation formation via the warm and ice phase, freezing depending on the availability of ice nuclei and detrainment of the cloud droplet and ice crystal number concentrations and mass mixing ratios to the stratiform cloud scheme. Previously cloud water in convective cores froze immediately upon supercooling below $0^{\circ} \mathrm{C}$. Now cloud droplets remain supercooled up to $-35^{\circ} \mathrm{C}$ depending on the liquid water content, the cloud droplet number concentration and the availability of freezing nuclei. In order to account for the accretion process, rain and snow that were formed in the preliminary updraft calculation have been saved for the final updraft calculations.

The results of the simulations for the present-day climate show that the higher amount of supercooled water in the mid troposphere increases the effective cloud amount in slightly better agreement with observations. In terms of precipitation changes over the 20th century, many observed features such as the decrease of precipitation in the Sahel zone or the increase in precipitation over South America and Central Africa are captured in the simulations that are forced by the changes in anthropogenic greenhouse gases and aerosols. In this simulation the convective precipitation increases the most suggesting that the convection has indeed become more vigorous as hypothesized by Khain et al. (2005). 
The total anthropogenic aerosol effect defined as the difference in net radiation at TOA between pre-industrial and present-day times is slightly smaller in simulation ECHAM5-conv amounting to $-1.5 \mathrm{~W} \mathrm{~m}^{-2}$ as compared to $1.6 \mathrm{~W} \mathrm{~m}^{-2}$ in ECHAM5-strat and $-1.9 \mathrm{~W} \mathrm{~m}^{-2}$ in ECHAM5acp.

As concluded in the Fourth IPCC report, the response of deep convective clouds to global warming is a substantial source of uncertainty in projections since current models predict different responses of these clouds (Randall et al., 2007). Thus, improvements in convective clouds need to go beyond including microphysics but should include improved cloud dynamics beyond the bulk mass flux approach. Examples for more sophisticated cloud dynamics schemes include the approach by von Salzen and McFarlane (2002), which accounts for an ensemble of transient shallow convective clouds or the approach by Graf and Yang (2007), which allows individual clouds to compete for the instability energy.

Acknowledgements. I thank P. Stier, H. Feichter, J. Zhang, C. Hoose, H. Graf and one anonymous reviewer for helpful comments and suggestions, C. Stubenrauch, G. Myhre and I. Koren for providing observational data, S. Ferrachat, M. Esch and C. LeDrian for technical help, and the German (DKRZ) and Swiss Computing Centres (CSCS) for computing time. This study contributed towards the Swiss climate research program NCCR Climate and the EU project EUCAARI.

Edited by: K. Carslaw

\section{References}

Ackerman, A. S., Kirkpatrick, M. P., Stevens, D. E., and Toon, O. B.: The impact of humidity above stratiform clouds on indirect climate forcing, Nature, 432, 1014-1017, 2004.

Adler, R. F., Huffman, G. J., Chang, A., Ferraro, R., Xie, P. P., Janowiak, J., Rudolf, B., Schneider, U., Curtis, S., Bolvin, D., Gruber, A., Susskind, J., Arkin, P., and Nelkin, E.: The version-2 global precipitation climatology project (GPCP) monthly precipitation analysis (1979-present), J. Hydrometeor., 4, 1147-1167, 2003.

Cui, Z. Q., Carslaw, K. S., Yin, Y., and Davies, S.: A numerical study of aerosol effects on the dynamics and microphysics of a deep convective cloud in a continental environment, J. Geophys. Res., 111, doi: 10.1029/2005JD005 981, d05201, 2006.

Del Genio, A. D., Yao, M.-S., and Jonas, J.: Will moist convection be stronger in a warmer climate?, Geophys. Res. Lett., 34, doi: 10.1029/2007GL030 525, 116703, 2007.

Denman, K., Brasseur, G., Chidthaisong, A., Ciais, P., Cox, P., Dickinson, R., Hauglustaine, D., Heinze, C., Holland, E., Jacob, D., Lohmann, U., Ramachandran, S., Silva Dias, P., Wofsy, S., and Zhang, X.: Couplings between changes in the climate system and biogeochemistry, in Climate Change 2007: The Physical Science Basis. Contribution of Working Group I to the Fourth Assessment Report of the Intergovernmental Panel on Climate Change, edited by S. Solomon, D. Qin, M. Manning, Z. Chen,
M. Marquis, K. B. Averyt, M. Tignor, and H. L. Miller, pp. 499588, Cambridge Univ. Press, Cambridge, United Kingdom and New York, NY, USA, 2007.

Dentener, F., Kinne, S., Bond, T., Boucher, O., Cofala, J., Generoso, S., Ginoux, P., Gong, S., Hoelzemann, J., Ito, A., Marelli, L., Penner, J., Putaud, J.-E., Textor, C., Schulz, M., van der Werf, G., and J., W.: Emissions of primary aerosol and precursor gases in the years 2000 and 1750 prescribed data-sets for AeroCom, Atmos. Chem. Phys., 6, 4321-4344, 2006, http://www.atmos-chem-phys.net/6/4321/2006/.

Feichter, J., Roeckner, E., Lohmann, U., and Liepert, B.: Nonlinear aspects of the climate response to greenhouse gas and aerosol forcing, J. Climate, 17, 2384-2398, 2004.

Ferraro, R., Weng, F., Grody, N., and Basist, A.: An Eight Year (1987-1994) Time Series of Rainfall, Clouds, Water Vapor, Snow-cover, and Sea-ice Derived from SSM/I Measurements, Bull. Amer. Meteorol. Soc., 77, 891-905, 1996.

Forster, P., Ramaswamy, V., Artaxo, P., Berntsen, T., Betts, R., Fahey, D. W., Haywood, J., Lean, J., Lowe, D. C., Myhre, G., Nganga, J., Prinn, R., Raga, G., Schulz, M., and Van Dorland, R.: Radiative Forcing of Climate Change, in Climate Change 2007: The Physical Science Basis. Contribution of Working Group I to the Fourth Assessment Report of the Intergovernmental Panel on Climate Change, edited by S. Solomon, D. Qin, M. Manning, Z. Chen, M. Marquis, K. B. Averyt, M. Tignor, and H. L. Miller, pp. 129-234, Cambridge Univ. Press, Cambridge, United Kingdom and New York, NY, USA, 2007.

Graf, H. F. and Yang, J.: Evaluation of a new convective cloud field model: precipitation over the maritime continent, Atmos. Chem. Phys., 7, 409-421, 2007,

http://www.atmos-chem-phys.net/7/409/2007/.

Greenwald, T. J., Stephens, G. L., Vonder Haar, T. H., and Jackson, D. L.: A Physical Retrieval of Cloud Liquid Water Over the Global Oceans Using Special Sensor Microwave/Imager (SSM/I) Observations, J. Geophys. Res., 98, 18,471-18,488, 1993.

Hahn, C. J., Warren, S. G., and London, J.: Climatological data for clouds over the globe from surface observations, 1982-1991: The total cloud edition, Tech. rep., ORNL/CDIAC-72 NDP-026A Oak Ridge National Laboratory, Oak Ridge Tennessee, U.S.A., 1994.

Han, Q., Rossow, W. B., and Lacis, A. A.: Near-Global Survey of Effective Droplet Radii in Liquid Water Clouds Using ISCCP Data, J. Climate, 7, 465-497, 1994.

Han, Q., Rossow, W. B., Chou, J., and Welch, R.: Global Variation of column droplet concentration in low-level clouds, Geophys. Res. Lett., 25, 1419-1422, 1998.

Held, I. M., Delworth, T. L., Lu, J., Findell, K. L., and Knutson, T. R.: Simulation of Sahel drought in the 20th and 21st centuries, Proc. Natl. Acad. Sci., 102, 17 891-17 896, 2005.

Hoose, C., Lohmann, U., Erdin, R., and Tegen, I.: Global influence of dust mineralogical composition on heterogeneous ice nucleation in mixed-phase clouds, Environ. Res. Lett., in press, 2008.

Hulme, M., Osborn, T. J., and Johns, T. C.: Precipitation sensitivity to global warming: Comparison of observations with HadCM2 simulations, Geophys. Res. Lett., 25, 3379-3382, 1998.

Jiang, H. L., Xue, H. W., Teller, A., Feingold, G., and Levin, Z.: Aerosol effects on the lifetime of shallow cumulus, Geophys. Res. Lett., 33, doi: 10.1029/2006GL026 024, 114806, 2006.

Kassianov, E. I., Berg, L. K., Flynn, C., and McFarlane, S.: The 
relevance of aerosol optical depth to cumulus fraction changes: a five-year climatology at the ACRF SGP site, Atmos. Chem. Phys. Discuss., 7, 11 797-11 837, 2007.

Khain, A., Pokrovsky, A., Pinsky, M., Seifert, A., and Phillips, V.: Simulation of Effects of Atmospheric Aerosols on Deep Turbulent Convective Using a Spectral Microphysics Mixed-Phase $\mathrm{Cu}-$ mulus Cloud Model. Part I: Model Description and Possible Applications, J. Aerosol Sci., 61, 2963-2982, 2004.

Khain, A., Rosenfeld, D., and Pokrovsky, A.: Aerosol impact on the dynamics and microphysics of deep convective clouds, Q. J. R. Meteorol. Soc., 131, 2639-2663, 2005.

Khain, A. P., Rosenfeld, D., and Pokrovsky, A.: Simulating convective clouds with sustained supercooled liquid water down to $-37.5^{\circ} \mathrm{C}$ using a spectral microphysics model, Geophys. Res. Lett., 28, 3887-3890, 2001.

Kiehl, J. T. and Trenberth, K. E.: Earth's Annual Global Mean Energy Budget, Bull. Amer. Meteorol. Soc., 78, 197-208, 1997.

King, M. D., Menzel, W. P., Kaufman, Y. J., Tanre, D., Gao, B. C., Platnick, S., Ackerman, S. A., Remer, L. A., Pincus, R., and Hubanks, P. A.: Cloud and aerosol properties, precipitable water, and profiles of temperature and water vapor from MODIS, IEEE Trans. Geo. Rem. Sens., 41, 442-458, 2003.

Kinne, S.: Aerosol Direct Radiative Forcing with an AERONET touch, Atmos. Env., subm. to, 2008.

Koren, I., Kaufman, Y. J., Rosenfeld, D., Remer, L. A., and Rudich, Y.: Aerosol invigoration and restructuring of Atlantic convective clodus, Geophys. Res. Lett., 32, doi:10.1029/2005GL023 187, 114828, 2005.

Lin, H. and Leaitch, W. R.: Development of an in-cloud aerosol activation parameterization for climate modelling, in Proceedings of the WMO Workshop on Measurement of Cloud Properties for Forecasts of Weather, Air Quality and Climate, pp. 328-335, World Meteorol. Organ., Geneva, 1997.

Lohmann, U.: Possible aerosol effects on ice clouds via contact nucleation, J. Atmos. Sci., 59, 647-656, 2002.

Lohmann, U. and Roeckner, E.: Design and performance of a new cloud microphysics scheme developed for the ECHAM general circulation model, Clim. Dyn., 12, 557-572, 1996.

Lohmann, U., Feichter, J., Chuang, C. C., and Penner, J. E.: Predicting the number of cloud droplets in the ECHAM GCM, J. Geophys. Res., 104, 9169-9198, 1999.

Lohmann, U., Stier, P., Hoose, C., Ferrachat, S., Kloster, S., Roeckner, E., and Zhang, J.: Cloud microphysics and aerosol indirect effects in the global climate model ECHAM5-HAM, Atmos. Chem. Phys., 7, 3425-3446, 2007, http://www.atmos-chem-phys.net/7/3425/2007/.

Menon, S. and Rotstayn, L.: The radiative influence of aerosol effects on liquid-phase cumulus and stratiform clouds based on sensitivity studies with two climate models, Climate Dyn., 27, 345-356, 2006.

Myhre, G., Stordal, F., Johnsrud, M., Kaufman, Y. J., Rosenfeld, D., Storelvmo, T., Kristjansson, J. E., Berntsen, T. K., Myhre, A., and Isaksen, I. S. A.: Aerosol-cloud interaction inferred from MODIS satellite data and global aerosol models, Atmos. Chem. Phys., 7, 3081-3101, 2007, http://www.atmos-chem-phys.net/7/3081/2007/.

Nober, F. J., Graf, H.-F., and Rosenfeld, D.: Sensitivity of the global circulation to the suppression of precipitation by anthropogenic aerosols, Global Planetary Change, 37, 57-80, 2003.
Nordeng, T. E.: Extended Versions of the Convective Parameterization Scheme at ECMWF and their Impact on the Mean and Transient Activity of the Model in the Tropics, Tech. Rep. 206, European Centre for Medium-Range Weather Forecasts, 1994.

Randall, D., Khairoutdinov, M., Arakawa, A., and Grabowski, W.: Breaking the cloud parameterization deadlock, Bull. Amer. Meteorol. Soc., 84, 1547-1564, 2003.

Randall, D., Wood, R., Bony, S., Colman, R., Fichefet, T., Fyfe, J., Kattsov, V., Pitman, A., Shukla, J., Srinivasan, J., Stouffer, R., Sumi, A., and Tayler, K.: Climate Models and Their Evaluation, in Climate Change 2007: The Scientific Basis. Contribution of working group I to the Forth Assessment Report of the Intergovernmental Panel on Climate Change, edited by S. Solomon, D. Qin, M. Manning, Z. Chen, M. Marquis, K. B. Averyt, M. Tignor, and H. L. Miller, pp. 589-662, Cambridge Univ. Press, Cambridge, United Kingdom and New York, NY, USA, 2007.

Roeckner, E., Bäuml, G., Bonaventura, L., Brokopf, R., Esch, M., Giorgetta, M., Hagemann, S., Kirchner, I., Kornblueh, L., Manzini, E., Rhodin, A., Schlese, U., Schulzweida, U., and Tompkins, A.: The atmospheric general circulation model ECHAM5. PART I: Model description, Tech. Rep. 349, MaxPlanck-Inst. für Meteorol., Hamburg, Germany, 2003.

Roeckner, E., Brokopf, R., Esch, M., Giorgetta, M., Hagemann, S., Kornblueh, L., Manzini, E., Schlese, U., and Schulzweida, U.: Sensitivity of simulated climate to horizontal and vertical resolution in the ECHAM5 atmosphere model, J. Climate, 19, 3771-3791, 2006.

Rogers, R. R. and Yau, M. K.: A Short Course in Cloud Physics, Pergamon, Tarrytown, N. Y., 1989.

Rosenfeld, D.: TRMM observed first direct evidence of smoke from forest fires inhibiting rainfall, Geophys. Res. Lett., 26, 31053108, 1999.

Rosenfeld, D. and Woodley, W. L.: Deep convective clouds with sustained supercooled liquid water down to $-37.5^{\circ} \mathrm{C}$, Nature, 405, 440-442, 2000.

Rossow, W. B. and Schiffer, R. A.: Advances in understanding clouds from ISCCP, Bull. Amer. Meteorol. Soc., 80, 2261-2287, 1999.

Rotstayn, L. D. and Lohmann, U.: Tropical rainfall trends and the indirect aerosol effect, J. Climate, 15, 2103-2116, 2002.

Schumacher, C. and Houze, R. A.: Stratiform rain in the tropics as seen by the TRMM precipitation radar, J. Climate, 16, 17391756, 2003.

Scott, N. A., Chedin, A., Armante, R., Francis, J., Stubenrauch, C., Chaboureau, J. P., Chevallier, F., Claud, C., and Cheruy, F.: Characteristics of the TOVS Pathfinder Path-B dataset, Bull. Amer. Meteorol. Soc., 80, 2679-2701, 1999.

Seifert, A. and Beheng, K. D.: A two-moment cloud microphysics parameterization for mixed-phase clouds. Part 2: Maritime vs. continental deep convective storms, Meteorol. Atmos. Phys., 92, 67-82, 2006.

Solomon, S., Qin, D., Manning, M., Alley, R. B., Berntsen, T., Bindoff, N. L., Chen, Z., Chidthaisong, A., Gregory, J. M., Hegerl, G. C., Heimann, H., Hewitson, B., Hoskins, B. J., Joos, F., Jouzel, J., Kattsov, V., Lohmann, U., Matsuno, T., Molina, M., Nicholls, N., Overpeck, J., Raga, G., Ramaswamy, V., Ren, J., Rusticucci, M., Somerville, R., Stocker, T. F., Whetton, P., A., W. R., and Wratt, D.: Technical Summary, in Climate Change 2007: The Physical Science Basis. Contribution of Working 
Group I to the Fourth Assessment Report of the Intergovernmental Panel on Climate Change, edited by S. Solomon, D. Qin, M. Manning, Z. Chen, M. Marquis, K. B. Averyt, T. M., and H. L. Miller, Cambridge Univ. Press, Cambridge, United Kingdom and New York, NY, USA, 2007.

Stier, P., Feichter, J., Kinne, S., Kloster, S., Vignati, E., Wilson, J., Ganzeveld, L., Tegen, I., Werner, M., Balkanski, Y., Schulz, M., Boucher, O., Minikin, A., and Petzold, A.: The aerosolclimate model ECHAM5-HAM, Atmos. Chem. Phys., 5, 11251156, 2005.

Storelvmo, T., Kristjansson, J.-E., and Lohmann, U.: Aerosol influence on mixed-phase clouds in CAM-Oslo, J. Atmos. Sci., in press, 2008.

Stubenrauch, C. J., Eddounia, F., and Sauvage, L.: Cloud heights from TOVS Path-B: Evaluation using LITE observations and distributions of highest cloud layers, J. Geophys. Res., 110, doi:10.1029/2004JD005 447, d19203, 2005.

Sundqvist, H., Berge, E., and Kristiansson, J. E.: Condensation and Cloud Parameterization Studies with a Mesoscale Numerical Weather Prediction Model, Mon. Wea. Rev., 117, 1641-1657, 1989.

Susskind, J., Piraino, P., Rokke, L., Iredell, T., and Mehta, A.: Characteristics of the TOVS Pathfinder Path A dataset, Bull. Amer. Meteorol. Soc., 78, 1449-1472, 1997.

Tao, W.-K., Li, X., Khain, A., Matsui, T., Lang, S., and Simpson, J.: Role of atmospheric aerosol concentration on deep convective precipitation: Cloud-resolving model simulations, J. Geophys. Res., 112, doi:10.1029/2007JD008 728, d24S18, 2007.

Tiedtke, M.: A Comprehensive Mass Flux Scheme for Cumulus Parameterization in Large-Scale Models, Mon. Weather Rev., 117, 3040-3061, 1989.
Tost, H., Jockel, P., and Lelieveld, J.: Influence of different convection parameterisations in a GCM, Atmos. Chem. Phys., 6, 54755493, 1680-7316, 2006.

Van den Heever, S., Carrio, G., Cotton, W. R., DeMott, P. J., and Prenni, A. J.: Impacts of nucleating aerosol on Florida convection, Part I: Mesoscale simulations, J. Aerosol Sci., 63, 17521775, 2006.

von Salzen, K. and McFarlane, N. A.: Parameterization of the bulk effects of lateral and cloud-top entrainment in transient shallow cumulus clouds, J. Atmos. Sci., 59, 1405-1430, 2002.

Weng, F. and Grody, N. C.: Retrieval of cloud liquid water using the special sensor microwave imager (SSM/I), J. Geophys. Res., 99, 25,535-25,551, 1994.

Williams, K. D., Jones, A., Roberts, D. L., Senior, C. A., and Woodage, M. J.: The response of the climate system to the indirect effects of anthropogenic sulfate aerosols, Clim. Dyn., 17, 845-856, 2001.

Yin, Y., Levin, A., Reisin, T. G., and Tzivion, S.: The effect of giant cloud condensation nuclei on the development of precipitation in convective clodus - a numerical study, Atmos. Res., 53, 91-116, 2000.

Zhang, J. H., Lohmann, U., and Stier, P.: A microphysical parameterization for convective clouds in the ECHAM5 climate model: Single-column model results evaluated at the Oklahoma Atmospheric Radiation Measurement Program site, J. Geophys. Res., 110, doi:10.1029/2004JD005 128, d15S07, 2005. 